\title{
Többpilléres tehetséggondozás a Kolozsvári Magyar Diákszövetségnél
}

KISGYÖRGY RÉKA - RÉS KONRÁD GERGELY

„A tudás a létezés hatalma.

A közösség a létezés erkölcse."

Szimeonov Todor

A forradalom éveiben Kolozsváron is elindultak a diákszerveződések, Babeş-Bolyai Tudományegyetem Bölcsészettudományi Karán. A szervezet megalakulására szükség volt, ezt tanúsítja, hogy az alakuló ülésen részt vett több, mint 250 hallgató. Az első években a diákszövetség fóként a magyar nyelvú oktatás újraindításáért küzdött. I990. március I2-20. között a diákszervezet 700-800 hallgató békés ülősztrájkját hirdette meg a magyar nyelvú oktatás újraindításának megtagadása miatt, valamint a marosvásárhelyi orvostanhallgatók hasonló jellegú akciójának támogatásaként. Már a megalakulási évben elindult a múködése a felvételi-információs irodának, amely a nyári és az ôszi egyetemi vizsgaidőszakban biztosított szolgáltatásokat a magyar felvételizők számára.

A diákszövetség a szakosztályok általi felépítés kialakult struktúrájának köszönhetően a Kolozsváron tanuló hallgatók nagy százalékához eljut a szervezet tevékenysége. Az egyetemi karokon szerveződő szakosztályok tevékenysége többrétú, fontos szerepet játszanak a hallgatók életében, számos szakmai rendezvényt szerveznek, amelyek specifikusan a hallgatók érdeklődési körére szabottak. A diákszövetségnek számos tehetséggondozási programja van, amelyek a szervezet éves tevékenységében kiemelt szerepet kapnak. Legnagyobb és legjelentősebb rendezvénye az Erdélyi 


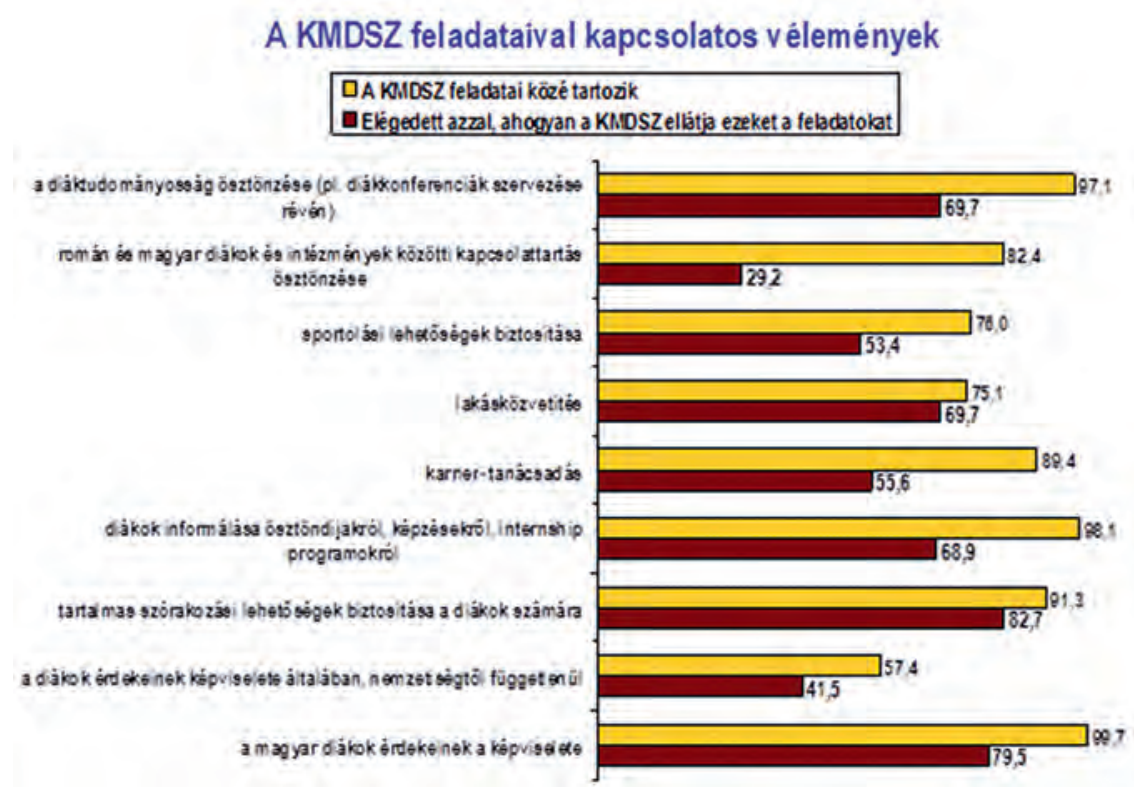

I. ÁBRA: A KMDSZ feladataival kapcsolatos vélemények

Tudományos Diákköri Konferencia, de emellett Karrierirodát múködtet, áthallgatásokat szervez, ösztöndijakat közvetít.

Egy, a 20I4. február-április közötti időszakban lezajlott online kérdőíves kutatást végeztünk, amelyet a Babeş-Bolyai Tudományegyetem Magyar Szociológia Intézete tervezett meg és bonyolított le az Igen, tessék! mozgalommal és a Kolozsvári Magyar Diákszövetséggel együttmúködésben (I. ábra). ${ }^{1}$

Többek között arról kérdeztük az egyetemi hallgatókat, hogy mit tartanak a KMDSZ feladatának, és azokkal mennyire vannak megelégedve. A diáktudományosság ösztönzése (konferenciaszervezés) a megkérdezettek 97,I\%-a szerint a KMDSZ feladata, és ennek megvalósításával 69,7\% van megelégedve. A karrier-tanácsadást $89,4 \%$ tartja a KMDSZ feladatának, és ennek megvalósulásával 55,6\% megelégedett. A diákok informálása ösztöndíjakról, képzésekről, gyakornoki programokról 98,I\% szerint a KMDSZ feladata, ezt 68,9\% szerint teljesíti. A kutatásból kitúnt, hogy a megkérdezettek 25,6\%-a vesz részt az Erdélyi Tudományos Diákköri Konferencián.

1 Csata Zsombor: A KMDSZ és a kolozsvári magyar diákok. 2014. 


\section{Tehetséggondozási programok}

\section{TUDOMÁNYOS}

\section{DIÁKKÖRI KONFERENCIA}

Az Erdélyi Tudományos Diákköri Konferencia (ETDK) hatékony hídként tud szolgálni a romániai és magyarországi diáktudományos kapcsolatok felépítésében, hiszen mint első fordulós megméretési fórum egyszerre őrzi meg a romániai, a tanulmányi kötelezettségeket meghaladó tudományos és múvészeti felsőoktatási diáktevékenység hagyományait és intézményi függetlenségét, és közben harmonikus módon bekapcsolja az ETDK-n szereplő legjobb munkákat a magyarországi Országos Tudományos Diákköri Konferenciák (OTDK) rendszerébe.

Az I990-es évek második felétől az Erdélyi Tudományos Diákköri Konferencia (ETDK) különböző szekcióinak szervezését az OMDSZ tagszervezetei kezdték meg. Az Országos Magyar Diákszövetség (OMDSZ) a romániai magyar felsőoktatásban tanuló diákok egységes országos szervezete. Az OMDSZ munkáját nyolc, a felsőoktatási központok szerint szerveződő tagszervezetén keresztül végzi, melyek közül a legnagyobb a Kolozsvári Magyar Diákszövetség.

Az OMDSZ-es kezdő évek óta az ETDK szerkezete mára kialakult: évente szerveződik, öt szekcióban, a következőképpen: Kolozsváron a reálés humántudományi szekció (fószervező a KMDSZ, a Kolozsvári Magyar Egyetemi Intézettel és a Babeş-Bolyai Tudományegyetemmel társszervezésben), Marosvásárhelyen az általános orvostudomány, fogorvostudomány és gyógyszerészet szekció (főszervező az MMDSZ az Orvosi és Gyógyszerészeti Egyetemmel, a Studium Alapítvánnyal, az Erdélyi MúzeumEgyesülettel és a Bod Péter Diakónia Központtal), Temesváron a múszaki tudományok szekció (főszervező a TMD), kezdetben Nagyváradon az agrártudományi szekció, ez később átkerült szintén Marosvásárhelyre, valamint Brassóban az erdészeti és faipari szekció (fószervező a BMD) ${ }^{2}$.

I998-ban 6 szekcióval indult a tudományos konferencia, 2015-ben a szekciók száma már elérte $33^{-a t}$ is.

Az ábrából levonható a következtetés, hogy a 20I4-es évben volt a legmagasabb a dolgozatszám (334), valamint ekkor az indult szekciók száma is a legmagasabb volt: 38 . Ezek a számok a dolgozatokat jelzik, a résztvevők száma minden egyes évben magasabb, hiszen maximum 5 szerzője lehet egy dolgozatnak.

2 Ez a szekció a 200o-es évek folyamán megszúnt. 


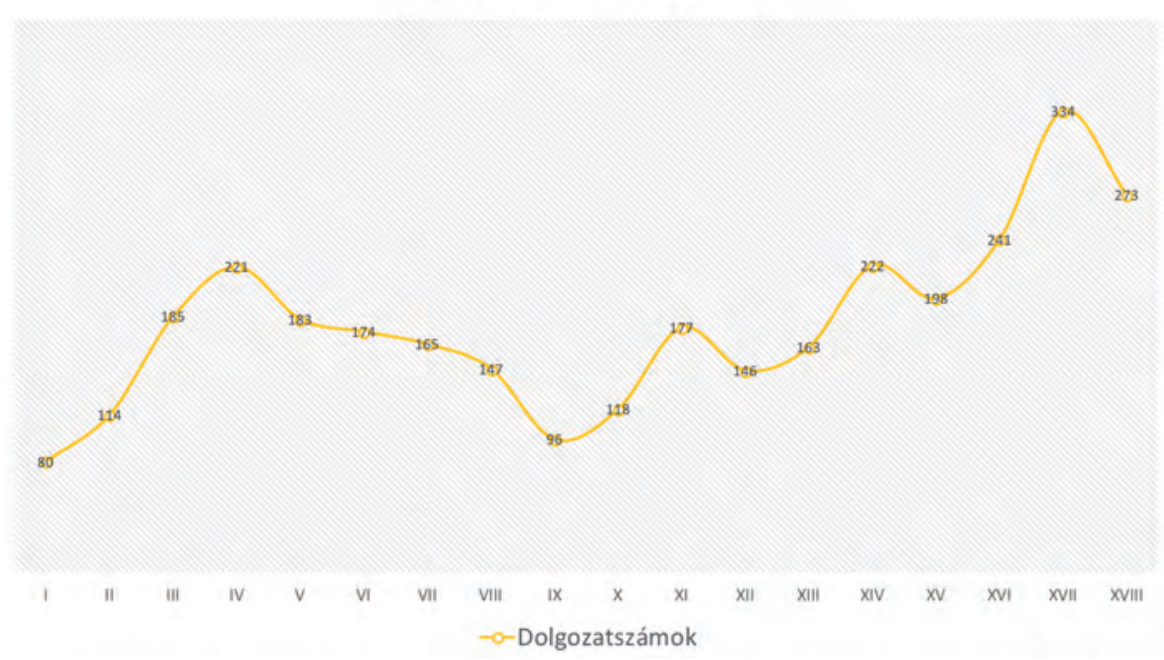

2. ÁBRA: Az ETDK reál-és humán tudományi szekcióiban benevezett pályamunkák adatai

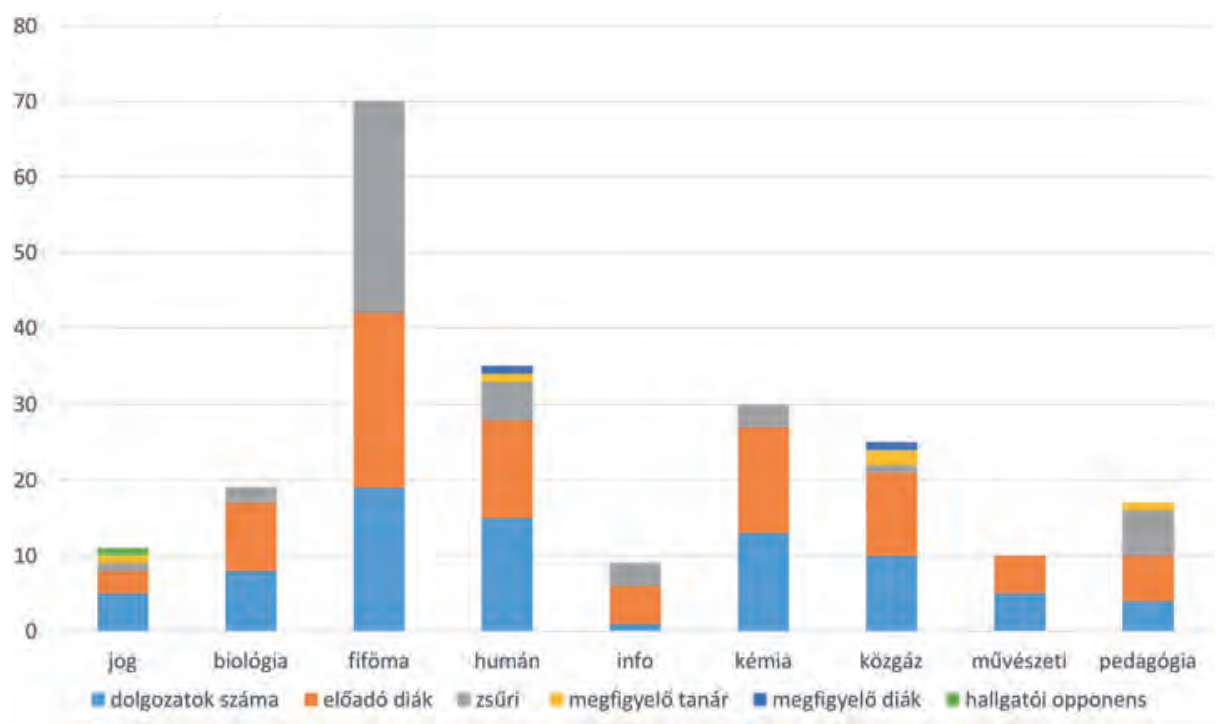

3. ÁBRA: Erdélyi résztvevoók szekció és részvételi státus szerint a XXXII. OTDK-n 


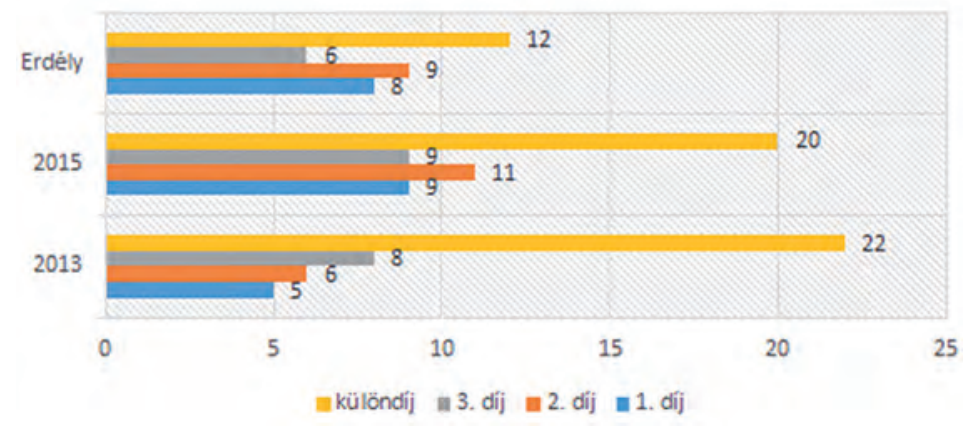

4. ÁBRA: Határon túli dijazott dolgozatok a XXXI. és XXXII. OTDK-n

Az ETDK évről évre történő erősödése következtében egyre több résztvevő jut ki az Országos Tudományos Diákköri Konferenciára is. 2005-ben 68 határon túli dolgozattal vettek részt, ez a szám növekedett I57-re.

$\mathrm{Az}$ OTDK határon túli részvételi aránya kétévente növekedik. Erdélyből a XXXII. OTDK-n 227 részvevő volt, amelyből I8I hallgató a kolozsvári ETDK-ról jutott tovább. A XXXII. OTDK-n számos szekcióban részt vettek szép számban a versenyző diákok mellett a megfigyelő diákok, tanárok és nem utolsósorban a zsúritagok.

A legkiemelkedőbb a FiFöMa szekció, amelyben 19 erdélyi dolgozatot mutatott be 23 elóadó diák, ebben a szekcióban az erdélyi zsúritag is a legtöbb volt, szám szerint 28 . Ez természetesen annak a hozadéka, hogy 20I5-ben először volt OTDK szervezve Erdélyben, ennek lebonyolításában oroszlánrészt vállalt a diákszövetség is.

Az elmúlt két OTDK-n milyen arányban voltak dijazottak a részvételhez viszonyitva? Elmondható, hogy a szám évról évre, ha kicsivel is, de növekedik. A harmadik ágon látható, hogy összességében a határon túli résztvevőkhöz viszonyítva az erdélyi hallgatók messzemenően több díjat hoznak haza.

A romániai magyar felsőoktatásban a diákok kötelező tanulmányokon túlmutató, önkéntes kutatómunkáját az elmúlt két évtizedben számos kiváló tanár- és diákkezdeményezés ösztönözte. E tanár-diák tudományos együttmúködésekből kialakuló múhelyek idővel intézményesedtek, így kialakultak a magyarországi tudományos diákkörökéhez hasonló feladatokat ellátó szakkollégiumok vagy tudományos múhelyek. Az egyetemi háttérintézmények megjelenése egyes helyszíneken és tudományterületeken már lehetőséget adott e múhelyek összefogására és ezáltal a stabilitásuk erősítésére is.

A TDK egész éves folyamat, szervezési előkészitésével egy külön koordinátorcsapat foglalkozik (folyamatos konzultáció az egyetemekkel, a 
szakkollégiumokkal, kutatói múhelyekkel) a tavasz folyamán számos tudományos rendezvényt szerveznek, amely elősegíti a diákok munkáját.

A konferenciát megelőzően számos előadás-sorozatot szervez a diákszövetség:

- Hogyan írjunk szakdolgozatot (tudományterületekre lebontva)

- Témavezetők és potenciális hallgatók találkozási fóruma

- Hivatkozások kezelése (tudományterületekre lebontva)

- Hogyan mutassuk be dolgozatunkat. A tökéletes prezentáció rejtelmei

ÁTHALLGATÁSOK

A KMDSZ őszi programjai közé tartozik a szegedi áthallgatás: a BabeşBolyai Tudományegyetem, a Kolozsvári Magyar Diákszövetség, valamint a Szegedi Tudományegyetem Bölcsészettudományi Karának Hallgatói Önkormányzata évente meghirdeti a Kolozsvár-Szeged hallgatói csereprogramot. A tanulmányút során a hallgatóknak lehetőségük van bejárni a vendéglátó egyetem óráira, megismerkedni a fogadó intézményen folyó oktatással, a várossal és az ottani diákszervezet tevékenységével.

Az első cserekapcsolatot a Szegedi Történészhallgatók Egyesülete és a Kolozsvári Magyar Történészhallgatók Egyesülete szervezte 1996 őszén. Az első félévet követő komoly érdeklődésnek köszönhetően úgy döntöttek, hogy az áthallgatást hosszú távon is szeretnék folytatni. Ezt követően a cserekapcsolat szervezése szegedi oldalon az egyetemistákból álló Garaboncziás Egyesület, kolozsvári oldalon pedig a KMDSZ (Kolozsvári Magyar Diákszövetség) hatáskörébe került.

A két egyetem közötti történelmi kapocs és a diákszervezetek jó viszonya évről évre biztosítja ennek a programnak a folytonosságát.

2012-től kezdődően a KMDSZ együttmúködik a MVM Paksi Atomerőmúvel, amely minden év nyarán két csoportot fogad egy kéthetes tanulmányútra az erőmúbe. Mindkét csoportba 6 foót Felvidékről és 6 foót az erdélyi, nappali tagozaton tanuló - diákigazolvánnyal rendelkező - magyar anyanyelvú, elsősorban múszaki szakirányon tanuló egyetemisták közül tudnak fogadni. Az MVM PA Zrt. ösztöndíjat biztosít a diákok számára, amely a szállást teljesen egészében, az étkezési és szabadidős programok költségét pedig nagy részben fedezi.

A szakmai program alatt a diákok megismerhetik az erőmú múködését, kapcsolódó létesítményeit, illetve tapasztalatokat szerezhetnek a saját - tanult - szakterületükön, ráadásul lehetőségük van szakmai kapcsolatok kialakítására. 


\section{KARRIERIRODA}

A pályaválasztás és az a folyamat, amelyen keresztül egy fiatal felelős szakemberré válik, hosszú és összetett folyamat, amely végleges kihatással van a szakmai jövőjére. A pályaválasztásban, az egyetem utáni munkaerőpiacon való elhelyezkedésben jelentős szerepet kell vállalniuk a karrierirodáknak és tanácsadó központoknak.

Az európai színvonalhoz képest, sajnos, Románia le van maradva a karrierközpontok múködésének tekintetében, számos egyetemnél múködik ugyan ilyen jellegú központ, viszont azoknak kapacitása nem elégséges az egyetemi hallgatók összlétszámához mérten.

Az ANOSR tanulmánya ${ }^{3}$ alapján - melyben a romániai felsőoktatási állami intézményeket kérdezték a karrierirodák és tanácsadó központok múködéséről - a következő eredmények olvashatók ki:

- a vizsgált 22 egyetemen 42 alkalmazott (átlagban I,9 fó van, aki pszichológus (COR 263402), pszichiáter (COR 263403) vagy karriertanácsadó (COR 242306);

- a vizsgált egyetemek felében nincs egyetlen alkalmazott sem, akinek képzettsége lenne a pszichológiai tanácsadásban - Kolozsváron a Gheorghe Dima Zeneakadémia van ebben a helyzetben;

- országos szinten I tanácsadó- és karrierközpont-alkalmazott jut 8493 hallgatóra.

Ezek az adatok nem azt jelentik, hogy az egyetemek nagy részében a hallgatók nem részesülnek pályaválasztási tanácsadásban, hanem azt, hogy aki ezzel a feladatkörrel foglalkozik, annak e munka nem az elsődleges tevékenységi körébe tartozik. Legtöbb esetben a tanárok, kutatásvezetők vállalják fel ezt a szerepet önkéntesen és olykor nem is tudatosan.

Az erdélyi magyar egyetemisták helyzete a pályaválasztás terén is eltérő problémákat mutat, hiszen sok esetben a nyelvi korlátok akadályt képeznek a sikeres karrier kiépítésében. Ezért is fontos, hogy országszerte a magyar diákszervezetek karrierirodákat múködtessenek.

A KMDSZ Karrieriroda fó tevékenysége:

- egyéni karriertanácsadás, életútmenedzsment,

- pályaorientációs tanácsadás,

- állásbörzék szervezése,

- elhelyezkedést segítő szolgáltatások biztosítása (önéletrajz-, motivációslevél-írás, önmenedzsment, álláskeresési technikák elsajátítása),

3 ANOSR-tanulmány: Serviciile de consiliere și orientare în carieră - Perspectiva studenților, 2014

84 KISGYÖRGY RÉKA - RÉS KONRÁD GERGELY 
- képzések, előadások és munkavállalási tréningek szervezése,

- cégbemutatók, munkahely-látogatások szervezése.

A karrierirodák fejlesztése prioritást élvez a diákszervezetek tevékenységében, viszont sajnos erdélyi viszonylatban nem támogatják elégségesen az ilyen jellegú irodák fenntartását.

\section{Szakosztályok}

A KMDSZ és szakosztályai, az egyetemi karokon belül múködő diákszervezetek nagy hatást gyakorolnak a kolozsvári diákközösségre, ugyanakkor a diákokra egyénileg is, hisz évente több, mint hetven programjukkal a diákközösség megerősítését, a diákok igényeinek kielégítését szolgálják. Kari gólyabál és gólyatábor mellett előadásokat, konferenciákat, bulikat szerveznek, ahol az adott kar diákjai együtt lehetnek.

\section{Összegzés}

A Kolozsvári Magyar Diákszövetség ezen tehetséggondozási programokkal ivódott be elsősorban a kolozsvári közösség tudatába, de a TDK által országszerte és az ország határain kívül is sikerül képviselnie a hallgatók érdekeit. A diákszövetség célja, hogy a hallgatók tudományos munkásságát ösztönözze, és folyamatos fejlődési lehetőséget biztosítson a számukra. A tehetséggondozás mellett a legfontosabb oktatási problémákkal is folyamatosan foglalkozik a diákszövetség, országos kezdeményezésekbe bekapcsolódva fóként az oktatás finanszírozásának növelését tartja fontosnak. Ez számos problémát megoldana, többek között a bentlakáshelyeket, az ösztöndíjakat, valamint hisszük, hogy a félbehagyott tanulmányok számaránya is kevesebb lenne. A Karrieriroda és az ETDK rendszerének erősítésével szeretnénk elérni, hogy a cégekkel, a civil szférával, illetve az egyetemekkel intézményes kapcsolat jöjjön létre, amelyek nemcsak támogatást nyújthatnak, hanem szakmai gyakorlatokat is kínálhatnak a hallgatóknak. 